\title{
HUBUNGAN ANTARA LINGKUNGAN KERJA FISIK DENGAN KESEHATAN DAN KESELAMATAN KERJA PADA PASUKAN KUNING DI KOTA PADANG
}

\author{
Harry Theozard Fikri, Rahma Dwi Putri,
}

Universitas Putra Indonesia "YPTK" Padang, email: harrytheozard@yahoo.com,rahmarestubunda@gmail.com

\begin{abstract}
This study aims to see whether there is a relationship between the Physical Work Environment and Occupational Health and Safety in the Yellow Forces in Padang City, with a population of 283 people.The sampling technique used is a simple random sampling technique, namely the technique of taking sample members from the population carried out randomly regardless of the strata that exist within the population. The number of samples in this study were 62 people. from 0.314 to 0.908 and the reliability coefficient is 0.931 . While the coefficient of validity on the occupational health and safety scale moves from 0.322 to 0.764 and the reliability coefficient is 0.942 . Hypothesis test results show the magnitude of the reliability coefficient of 0.479 with a significant level of $p=0,000$ meaning that it can be concluded that there is a significant relationship between the work environment and occupational health and safety, with a positive direction. This means that if the research has a high work environment then work health and safety will also be high. Likewise, if you have a low physical work environment, eating health and safety will also be low. The effective contribution Environment with of the Physical WorkOccupational Health and Safety in the Yellow Forces in the City of Padang is $23 \%$.
\end{abstract}

Keywords: Physical Work Environment, Occupational Health and Safety, Yellow Troops

\begin{abstract}
ABSTRAK
Penelitian ini bertujuan untuk melihat apakah terdapat hubungan Antara Lingkungan Kerja Fisik Dengan Kesehatan dan Keselamatan Kerja Pada Pasukan Kuning di Kota Padang yang populasinya berjumlah 283 orang.Teknik sampling yang digunakan adalah teknik simple random sampling, yaitu teknik pengambilan anggota sampel dari populasi dilakukan secara acak tanpa memperhatikan strata yang ada didalam populasi itu.Jumlah sampel dalam penelitian ini sebanyak 62 orang.Hasil uji coba menunjukan koefisien validitas pada skala lingkungan fisik kerja bergerak dari 0,314 sampai dengan 0,908 dan koefisien reliabilitas sebesar 0,931. Sedangkan koefisien validitas pada skala kesehatan dan keselamatan kerja bergerak dari 0,322 sampai dengan 0,764 dan koefisien reliabilitas sebesar 0,942 . Hasil uji hipotesis menunjukan besar koefisien reliabilitas sebesar 0,479 dengan taraf signifikan $\mathrm{p}=0,000$ artinya dapat disimpulkan terdapat hubungan yang signifikan antara lingkungan kerja dengan kesehatan dan keselamatan kerja, dengan arah positif. Hal ini berarti apabila penelitian memiliki lingkungan kerja yang tinggi maka kesehatan dan keselamatan kerja juga akan tinggi. Begitu juga sebaliknya apabila memiliki lingkungan kerja fisik yang rendah makan kesehatan dan keselamatan kerja juga akan rendah. Besar sumbangan efektif Lingkungan Kerja Fisik Dengan Kesehatan dan Keselamatan Kerja Pada Pasukan Kuning di Kota Padang adalah sebesar 23 \%.
\end{abstract}

Kata kunci: Lingkungan Kerja Fisik, Kesehatan dan Keselamatan Kerja, Pasukan Kuning 


\section{A. PENDAHULUAN}

Pekerjaan adalah salah satu domain untuk memperoleh kebahagiaan dalam hidup seperti diri sendiri, keluarga, pernikahan, relasi, lingkungan sosial, fisik, kerja dan pendidikan (Carr dalam Prasetyo, 2015)[1]. Salah satu jenis pekerjaan yang rentan menimbulkan kecelakaan dan masalah kesehatan kerja adalah petugas kebersihan (Fakhrina \& Asniar, 2017) ${ }^{[2]}$.

Petugas kebersihan kota atau biasa disebut dengan "pasukan kuning" adalah sebutan bagi kelompok profesi yang bekerja untuk membersihkan sampah perkotaan (Maharani, 2018) ${ }^{[3] \cdot}$ Sebagai pekerjaan dan sumber mata pencaharian, membersihkan sampah adalah aktivitas rutin yang dilakukan setiap hari dari subuh hingga malam hari. Pekerja menggunakan seragam berwarna kuning dilengkapi dengan sapu lidi, sekop, pemotong rumput dan karung sampah sudah menjadi bagian dari simbol yang tidak bisa dipisahkan dari tempat dimana mereka bekerja..

Pasukan kuning yang bekerja dilapangan mereka lebih banyak bergerak dan terkena cahaya matahari dan memiliki risiko yang tinggi dalam bekerja seperti kecelakaan kerja. Kecelakaan kerja adalah suatu kejadian atau peristiwa yang tidak diinginkan yang merugikan terhadap manusia, merusak harta benda atau kerugian terhadap proses (Sugeng dalam Saputra, 2012) [4]. $^{[4}$

Kecelakaan kerja yang sering terjadi pada pasukan kuning diakibatkan karena pekerjaan mereka yang selalu terpapar oleh alat-alat pemotong rumput dan penanganan alat berat dan bahaya dari semua kendaraan yang lewat disekitar tempat mereka bekerja. Selain itu pasukan kuning berisiko tinggi mengalami masalah kesehatan karena terpapar langsung dengan pembuangan sampah (Marlini dalam Fakhrina \& Asniar, 2017) ${ }^{[2]}$.

Pasukan kuning memiliki banyak kesulitan, tantangan dan resiko yang tinggi dalam bekerja yang bisa menyebabkan kematian akan tetapi mereka tetap gigih dan semangat mengerjakan pekerjaan untuk menghidupi keluarganya. Rendahnya kesadaran masyarakat dalam prakteknya selalu membuang sampah pada bukan pada tempat yang telah disediakan oleh pihak dinas kebersihan menjadi permasalahan juga yang dihadapi oleh pasukan kuning. Melihat dampak yang ditimbulkan oleh sampah tersebut, maka pasukan kuning perlu suatu penanganan yang lebih ekstra untuk mencegah lebih lanjut masalah kecelakan kerja, kesehatan serta keselamatan dalam kerja.

Kesehatan dan keselamatan kerja (K3) adalah salah satu bentuk upaya untuk menciptakan tempat kerja yang aman, sehat, bebas dari pencemaran lingkungan sehingga dapat melindungi dan bebas dari kecelakaan kerja dan pada akhirnya dapat meningkatkan efisiensi dan produktivitas kerja. Faktor-faktor yang mempengaruhi kesehatan dan keselamatan kerja (K3) adalah faktor kebersihan, faktor air minum dan kesehatan, faktor urusan rumah tangga, faktor ventilasi, pemanas dan pendingin, ruang kerja dan tempat duduk, faktor pencegahan kecelakaan, faktor pencegahan kebakaran, faktor penerangan/cahaya, warna dan suara bising di tempat kerja serta faktor tempat kerja (Irzal, 2016) ${ }^{[5]}$.

Nitisemito (2016) ${ }^{[6]}$ mendefinisikan lingkungan kerja fisik sebagai segala sesuatu yang ada di sekitar para pekerja yang dapat mempengaruhi dirinya dalam menjalankan tugas-tugas yang dibebankan, misalnya penerangan, suhu udara, ruang gerak, keamanan, kebersihan, musik dan lainlain. Lingkungan kerja terbagi menjadi dua yaitu lingkungan kerja fisik dan lingkungan kerja non fisik.

Lingkungan kerja fisik adalah semua yang terdapat disekitar tempat kerja yang dapat mempengaruhi pekerja baik secara langsung maupun tidak langsung Untuk memperkecil pengaruh lingkungan kerja fisik terhadap pasukan kuning, maka langkah pertama adalah harus mempelajari manusia, baik mengenai sifat dan tingkah lakunya maupun mengenai fisiknya, kemudian digunakan sebagai dasar memikirkan lingkungan fisik yang sesuai. Suatu kondisi lingkungan dikatakan baik atau sesuai apabila manusia dapat melaksanakan kegiatannya secara optimal, sehat, aman dan nyaman (Sedarmayanti, 2011) ${ }^{[7] .}$

Lingkungan kerja fisik merupakan salah satu faktor yang mempengaruhi kinerja pasukan kuning dimana secara langsung akan mendukungnya untuk bekerja secara optimal dan menghasilkan kinerja yang baik pula dan begitu juga sebaliknya apabila seorang petugas bekerja dilingkungan 
kerja fisik yang tidak mendukung atau kurang memadai untuk bekerja secara optimal maka akan membuat pasukan kuning tersebut menjadi tidak nyaman, cepat lelah, malas sehingga mengganggu aktifitasnya dalam bekerja.

Berdasarkan hasil wawancara yang peneliti lakukan pada tanggal 16 Oktober 2018 terhadap kepala bidang kebersihan dan pertamanan diperoleh keterangan bahwa seluruh petugas kebersihan mendapatkan alat pelindung diri (APD) yang lengkap. Setiap memulai tugas mereka biasanya berkumpul, kemudian ada bagian pengawasan yang selalu mencek kelengkapan alat pelindung diri (APD).Meskipun begitu, ternyata masih banyak petugas yang tidak mengenakan alat pelindung diri (APD) yang lengkap sehingga sering kali terdapat kecelakaan kerja. Biasanya yang rentan mengalami kecelakaan kerja adalah shift pagi karena mereka mulai bekerja dari subuh dan penerangan masih terbatas. Selain itu, diketahui bahwa para petugas pasukan kuning terbagi atas dua shift, yaitu shift pagi yang diakhiri kurang dari jam 7 pagi dan shift sore yang dimulai jam 3 sore.

Berdasarkan hasil wawancara lanjutan yang peneliti lakukan pada 10 orang pasukan kuning, diperoleh keterangan bahwa pasukan kuning seringkali merasa tidak nyaman dan merasa terancam pada saat melakukan tugasnya. Hal ini terjadi karena beberapa kali para petugas tertabrak oleh kendaraan yang lewat karena para pengedara kendaraan tidak menyadari adanya kehadiran para pasukan kuning yang sedang melakukan tugas ditepi jalan, minimnya penerangan/cahaya lampu dan juga sering terjadi kecelakaan kerja karena para pasukan kuning tidak menggunakan alat pelindung diri (APD) yang lengkap seperti tidak memakai helm, masker sepatu kerja yang mengakibatkan mudahnya debu dan bau sampah terhirup oleh pasukan kuning yang berdampak pada kesehatan dan keselamatan kerja pasukan kuning. Dampak yang ditimbulkan lainnya adalah pasukan kuning terkena penyakit kulit seperti gatal-gatal, diare, batuk-batuk dan infeksi saluran pernafasan karena banyaknya kuman dan bibit penyakit yang ada dilingkungan pasukan kuning bekerja dan sesekali pasukan kuning terpijak beling/kaca pada kaki pasukan kuning yang menyebabkan luka.Pasukan kuning yang bekerja di shift pagi sering mengalami rasa mengantuk, sering menguap, lemas, pusing dan kaku pada bagian tubuh tertentu ketika bekerja akibat kurangnya istirahat. Beberapa kali anggota tubuh pasukan kuning terkena batu maupun kerikil yang terpental secara tidak sengaja akibat terlindas oleh pengendara kendaraan bermotor. Hal ini disebabkan karena pasukan kuning yang bekerja sering merasa bahwa tidak nyaman ketika bekerja dilapangan mengingat resiko yang cukup tinggi, pasukan kuning sering berpikir jika melakukan kesalahan dan tidak fokus dalam bekerja tentu nantinya akan berdampak terhadap kecelakaan kerja, kesehatan dan keselamatan mereka ketika bekerja.

\section{B. LANDASAN TEORI}

\section{Kesehatan dan Keselamatan Kerja}

Nitisemito (2016) ${ }^{[6]}$ mendefinisikan lingkungan kerja fisik sebagai segala sesuatu yang ada di sekitar para pekerja yang dapat mempengaruhi dirinya dalam menjalankan tugas-tugas yang dibebankan, misalnya penerangan, suhu udara, ruang gerak, keamanan, kebersihan, musik dan lain-lain. Kesehatan dan keselamatan kerja (K3) adalah salah satu bentuk upaya untuk menciptakan tempat kerja yang aman, sehat, bebas dari pencemaran lingkungan sehingga dapat melindungi dan bebas dari kecelakaan kerja dan pada akhirnya dapat meningkatkan efisiensi dan produktivitas kerja (Irzal, 2016) ${ }^{[5]}$

Berdasarkan uraian di atas, maka dapat disimpulkan bahwa kesehatan dan keselamatan kerja adalah suatu pemikiran dan upaya untuk menjamin keutuhan dan kesempurnaan jasmani maupun rohani tenaga kerja khususnya dan manusia pada umumnya serta hasil karya dan budaya menuju masyarakat adil dan makmur.

\section{Aspek-aspek Kesehatan dan Keselamatan Kerja}

Irzal (2016 $)^{[5]}$ menyebutkan aspek-aspek kesehatan dan keselamatan kerja adalah: 
1. Tempat kerja, peralatan, lingkungan kerja dan tata cara kerja diatur demikian rupa sehingga tenaga kerja terlindungi dari kecelakaan.

2. Harus menjamin bahwa mesin-mesin peralatan, kendaraan atau peralatan lain harus aman digunakan dan sesuai persyaratan keselamatan kerja

3. Persyaratan teknis pengaturan keselamatan dan kesehatan kerja dilingkungan kerja seperti pintu masuk dan keluar harus dibuat dan dipelihara dengan baik, lampu dan penerangan, ventilasi udara, kebersihan, peralatan perlindungan diri, peralatan pemadam kebalaran dan saluran air, pengelolaan syarat bahan kimia, peralatan dan pemasangan instalasi

4. Pengelola harus turut mengawasi agar tenaga kerja bisa selamat dan aman dalam bekerja.

5. Pengelola harus menunjuk petugas keselamatan kerjayang karena jabatannya dalam organisasi, bertanggung jawab mengawasi koordinasi pekerjaan yang dilakukan, untuk menghindari resiko bahaya kecelakaan.

6. Pekerjaan yang diberikan harus cocok dengan keahlian, usia, jenis kelamin, dan kondisi fisik serta kesehatan tenaga kerja.

7. Pengelola harus menjamin bahwa semua tenaga kerja telah diberi petunjuk terhadap bahaya kecelakaan yang mungkin terjadi serta usaha pencegahannya.

8. Petugas keselamatan kerja bertanggung jawab terhadap semua tempat kerja, peralatan, sarana pencegahan kecelakaan, lingkungan kerja dan prosedur/cara-cara pelaksanaan kerja yang aman.

9. Hal-hal yang menyangkut biaya yang timbul dalam penyelenggaraan keselamatan dan kesehatan kerja menjadi tanggung jawab pengelola.

\section{Pengertian Lingkungan Kerja Fisik}

Lingkungan kerja fisik adalah lingkungan kerja yang meliputi beberapa aspek yang harus diperhatikan misalnya ruangan kerja yang nyaman, kondisi lingkungan yang aman, suhu ruangan yang tetap, terdapat pencahayaan yang memadai, warna cat ruangan (Serdamayanti, 2011) (7]. $^{\text {. }}$

Nitisemito (2016) ${ }^{[6]}$ mendefinisikan lingkungan kerja fisik sebagai segala sesuatu yang ada di sekitar para pekerja yang dapat mempengaruhi dirinya dalam menjalankan tugas-tugas yang dibebankan, misalnya penerangan, suhu udara, ruang gerak, keamanan, kebersihan, musik dan lain-lain.

Berdasarkan uraian di atas, maka dapat disimpulkan bahwa lingkungan kerja fisik adalah segala sesuatu yang ada di sekitar tempat kerja karyawan lebih banyak berfokus pada bendabenda dan situasi sekitar tempat kerja sehingga dapat mempengaruhi karyawan dalam melaksanakan tugasnya.

\section{Komponen Dukungan Sosial}

Menurut Nitisemito (2016) ${ }^{[6]}$ indikator lingkungankerja fisik adalah sebagai berikut:

1. Pewarnaan. Masalah pewarnaan ini bukan hanya dindingsajatetapi sangat luas sehingga dapatjuga pewarnaan mesin, peralatan, bahkan seragam yangdipakai perlu mendapat perhatian.

2. Kebersihan. Secaraumumtempatkerja yang bersih akanmenimbulkan rasa senang dan rasa senang akan mempengaruhi perasaan dan perilaku orang dalambekerja.

3. Penerangan. Penerangan disini bukanlah terbatas pada penerangan listrik tetapijuga penerangan matahari.Dalammelaksanakan tugasnya seringkali karyawan membutuhkan penerangan yang cukup, apalagijika pekerjaan tersebut membutuhkan keahlian.

4. Pertukaran udara. Pertukaran udara yang cukup terutama dalam ruang kerja sangat diperlukan apalagi jika dalam ruangan tersebut penuh dengan karyawan Pertukaran udara yang cukup akan menyebabkan kesegaran fisik dari para karyawan. Sebaliknya, pertukaran udara yang kurang akan dapat menimbulkan rasa pengap sehingga terjadi kelelahan dari para karyawan sehingga motivasi karyawan untuk menyelesaikan tugas-tugasnya menjadi turun. 


\section{HIPOTESIS}

Hipotesis yang akan diajukan dalam penelitian ini adalah terdapat hubungan antara lingkungan kerja fisik dengan kesehatan dan keselamatan kerja pada pasukan kuning di kota Padang.

\section{METODE PENELITIAN.}

\section{Indentifikasi Variabel Penelitian}

Menurut Sugiyono (2014) ${ }^{[8]}$ variabel penelitian adalah suatu atribut atau sifat atau nilai dari orang, objek atau kegiatan yang mempunyai variasi tertentu yang ditetapkan oleh peneliti untuk dipelajari dan kemudian ditarik kesimpulannya. Adapun variabel yang diukur dalam penelitian ini adalah sebagai berikut:
a. Variabel independen
: Lingkungan Kerja Fisik (X)

b. Variabel dependen : Kesehatan dan Keselamatan Kerja(Y)

\section{Definisi Operasional Veriabel Penelitian}

Definisi operasional adalah suatu definisi mengenai variabel yang dirumuskan berdasarkan karakteristik-karakteristik yang dapat dimengerti (Azwar, 2014) ${ }^{[9]}$.

\section{a. Lingkungan Kerja Fisik}

Lingkungan kerja fisik adalah segala sesuatu yang ada di sekitar tempat kerja karyawan lebih banyak berfokus pada benda-benda dan situasi sekitar tempat kerja sehingga dapat mempengaruhi karyawan dalam melaksanakan tugasnya.Dalam penelitian ini lingkungan kerja fisik diukur dengan menggunakan skala psikologi yang disusun berdasarkan empat indikator lingkungan kerja fisik yaitu pewarnaan, kebersihan, penerangan dan pertukaran udara.

\section{b. Kesehatan dan Keselamatan Kerja}

Kesehatan dan keselamatan kerja adalah suatu pemikiran dan upaya untuk menjamin keutuhan dan kesempurnaan jasmani maupun rohani tenaga kerja khususnya dan manusia pada umumnya serta hasil karya dan budaya menuju masyarakat adil dan makmur. Dalam penelitian ini kesehatan dan keselamatan kerja diukur dengan menggunakan skala psikologi yang disusun berdasarkan sembilan aspek kesehatan dan keselamatan kerja yaitu tempat kerja, fasilitas pendukung, persyaratan teknis pengaturan kesehatan dan keselamatan kerja, fungsi pengawas pimpinan, pengawas dilapangan, pekerjaan yang diberikan harus cocok dengan keahlian, pelatihan yang diberikan kepada petugas, safety prosedur dan jaminan kesehatan kerja.

\section{Populasi dan Sampel}

\section{a. Populasi}

Populasi adalah wilayah generalisasi yang terdiri atas objek atau subjek yang mempunyai kualitas dan karakteristik tertentu yang ditetapkan peneliti untuk dipelajari dan kemudian ditarik kesimpulannya (Sugiyono, 2014) ${ }^{[8]}$.Populasi dalam penelitian ini adalah seluruh pasukan kuning di kota Padang yang berjumlah 283 orang.

\section{b. Sampel}

Sampel adalah sebagian dari jumlah dan karakteristik yang dimiliki oleh populasi tersebut (Sugiyono, 2009) ${ }^{[8]}$. Teknik pengambilan sampel dalam penelitian ini menggunakan teknik simple random sampling dimana peneliti mencampur subjek-subjek di dalam populasi sehingga semua subjek dianggap sama (Arikunto, 2010) ${ }^{[10]}$. Jumlah pasukan kuning yang dapat digunakan sebagai sampel penelitian adalah sebanyak 62 orang. 


\section{Teknik Pengambilan Data}

\section{a. Alat ukur}

Alat ukur yang digunakan dalam penelitian ini adalah berupa skala optimisme dan skala dukungan sosial.Skala yang digunakan dalam format respon jawaban adalah skala model likert untuk mendapatkan data kuantitatif. Skala ini digunakan untuk mengukur sikap, pendapat, dan persepsi seseorang atau sekelompok orang tentang fenomena sosial (Sugiyono, $2014)^{[8]}$.

Skala dalam penelitian ini memiliki format respon dengan empat alternatif jawabannya yaitu SS/sangat setuju, S/setuju, TS/tidak setuju dan STS/sangat tidak setuju. Peneliti tidak menggunakan respon tengah "R/ragu-ragu.

\section{1) Skala Kesehatan dan Keselamatan Kerja}

Dalam penelitian ini kesehatan dan keselamatan kerja diukur dengan menggunakan skala psikologi yang disusun berdasarkan sembilan aspek kesehatan dan keselamatan kerja yaitu tempat kerja, fasilitas pendukung, persyaratan teknis pengaturan kesehatan dan keselamatan kerja, fungsi pengawas pimpinan, pengawas dilapangan, pekerjaan yang diberikan harus cocok dengan keahlian, pelatihan yang diberikan kepada petugas, safety prosedur dan jaminan kesehatan kerja.

\section{2) Skala Lingkungan Kerja Fisik}

Dalam penelitian ini lingkungan kerja fisik diukur dengan menggunakan skala psikologi yang disusun berdasarkan empat indikator lingkungan kerja fisik yaitu pewarnaan, kebersihan, penerangan dan pertukaran udara.

\section{b. Uji Coba Alat Ukur \\ 1) Uji Validitas}

Validitas berasal dari kata validity yang mempunyai arti sejauh mana ketepatan dan kecermatan suatu alat ukur dalam melakukan fungsi ukurnya (Sugiyono, 2014) ${ }^{[8]}$. Pengukuran validitas konstruksi yang digunakan dalam penelitian ini adalah dengan menggunakan teknik korelasi product moment dengan bantuan program SPSS versi 21,0 (Azwar, 2014) ${ }^{[9]}$. Peneliti menentukan aitem valid atau tidaknya alat ukur menggunakan kriteria $r_{x y} \geq 0,3$ (Azwar, 2014) ${ }^{[9]}$. Data skala dikatakan valid jika koefisien korelasi lebih besar atau sama dengan $0,3\left(\mathrm{r}_{\mathrm{xy}} \geq 0,3\right)$ dan sebaliknya aitem skala dikatakan gugur jika koefisien korelasi lebih kecil dari $0,3\left(\mathrm{r}_{\mathrm{xy}}<0,3\right)$.

\section{2) Uji Reabilitas}

Reliabilitas sebenarnya mengacu kepada konsistensi atau keterpercayaan hasil ukur, yang mengandung makna kecermatan pengukuran. Pengukuran yang tidak cermat berarti juga tidak akan konsisten dari waktu kewaktu (Azwar, 2014) ${ }^{[9]}$. Koefisien reliabilitas berada dalam rentang angka dari 0 sampai dengan 1,00. Sekalipun bila koefisien reliabilitas semakin tinggi mendekati angka 1,00 berarti pengukuran semakin reliabel (Azwar, 2014) ${ }^{[9]}$. Sebaliknya koefesien yang semakin rendah mendekati 0 berarti semakin rendahnya reliabilitas.

3) Validitas Skala Kesehatan dan Keselamatan Kerja

Koefesien validitas ditetapkan sebesar 0,30 sehingga diperoleh hasil dari 54 aitem awal diperoleh 39 aitem yang valid dan 15 aitem yang gugur. dengan nilai corrected item-total correlation berkisar antara 0,322 sampai dengan 0,764.

\section{4) Validitas Skala Lingkungan Kerja Fisik}

Koefisien validitas ditetapkan sebesar 0,30 sehingga diperoleh hasil dari jumlah aitem awal 40 aitem diperoleh 31 aitem yang valid dan 9 aitem yang gugur dengan nilai corrected item-total correlation berkisar antara 0,314 sampai dengan 0,908. 


\section{5) Reabilitas Skala Lingkungan Kerja Fisik dan Skala Kesehatan dan Keselamatan Kerja}

Reliabilitas skala orientasi masa depan pada penelitian ini menggunakan teknik analisisAlpha Cronbach. Koefisien reliabilitas untuk skala lingkungan kerja fisik diperoleh sebesar $\alpha=0,931$ artinya derajat reliabilitas tinggi, maka dapat disimpulkan bahwa butir-butir alat instrumen penelitian tersebut reliabel sedangkan untuk skala kesehatan dan keselamatan kerjadiperoleh sebesar $\alpha=$ 0,942 artinya derajat reliabilitas tinggi, maka dapat disimpulkan bahwa butir-butir alat instrumen penelitian tersebut reliabel.

\section{E. HASIL DAN PEMBAHASAN}

\section{Pelaksaan Penelitian}

Sampel penelitian ini adalah pasukan kuning yang seb ada sebanyak 62 orang.

\section{Analisis Data}

\section{a. Uji Normalitas}

Uji normalitas dalam penelitian ini menggunakan uji Kolmogorov-Smirnov. Priyatno $(2008)^{[11]}$ menyatakan bahwa data yang dinyatakan berdistribusi normal jika signifikansi (p) lebih besar dari 0,05. Berdasarkan hasil pengolahan data dengan menggunakan program IBM SPSS 21.0, maka diperoleh hasil sebagai berikut:

Tabel 1.

Uji Normalitas Skala Dukungan Sosial dengan Optimisme

\begin{tabular}{|c|c|c|c|c|}
\hline Variabel & N & KSZ & p & Sebaran \\
\hline Lingkungan kerja fisik & 62 & 0,992 & 0,278 & Normal \\
\hline $\begin{array}{c}\text { Kesehatan dan } \\
\text { keselamatan kerja }\end{array}$ & 62 & 0,765 & 0,602 & Normal \\
\hline
\end{tabular}

Nilai signifikansi pada skala lingkungan kerja fisik sebesar $\mathrm{p}=0,278$ dengan $\mathrm{KSZ}=$ 0,992 . Hasil tersebut menunjukkan bahwa nilai $\mathrm{p}>0,05$, artinya sebaran berdistribusi secara normal sedangkan untuk skala kesehatan dan keselamatan kerjadiperoleh nilai signifikansi sebesar $\mathrm{p}=0,602$ dengan $\mathrm{KSZ}=0,765$. Hasil tersebut menunjukkan bahwa nilai $\mathrm{p}>0,05$, artinya sebaran berdistribusi secara normal..

b. Uji Linieritas

Uji linieritas bertujuan untuk mengetahui apakah dua variabel mempunyai hubungan yang linier atau tidak. Dua variabel dikatakan mempunyai hubungan yang linier bila signifikansi (Linearity) kurang dari 0,05 (Priyatno, 2008) ${ }^{[9]}$. Berdasarkan hasil pengolahan data dengan menggunakan program IBM SPSS 21.0, maka diperoleh hasil sebagai berikut:

Tabel 2.

Uji Linieritas Skala Dukungan Sosial dengan Optimisme

\begin{tabular}{|c|c|c|c|c|}
\hline $\mathbf{N}$ & df & Mean Square & F & Sig \\
\hline 62 & 1 & 3598,255 & 19,153 & 0,000 \\
\hline
\end{tabular}

Signifikansi sebesar $\mathrm{p}=0,000(\mathrm{p}<0,05)$, artinya varians pada skala lingkungan kerja fisik dan skala kesehatan dan keselamatan kerjatergolong linier. 


\section{c. Uji Hipotesis}

Pengolahan data penelitian tentang hubungan antara Dukungan Sosial dengan Optimisme terhadap Masa Depan pada 85 mantan narapidana bebas bersyarat yang sedang menjalani masa wajib lapor di Balai Pemasyarakatan Klas I Padang, dengan menggunakan uji statistikProduct Moment dengan bantuan IBM SPSS Statistics versi 21.0, dapat dilihat pada table berikut:

Tabel 5.

Hasil Uji Korelasi Antara Skala Dukungan Sosial dengan Optimisme

\begin{tabular}{|c|c|c|c|c|l|}
\hline $\mathbf{N}$ & $\mathbf{p}$ & $(\boldsymbol{\alpha})$ & $\begin{array}{c}\text { Nilai Korelasi } \\
(\mathbf{r})\end{array}$ & Rsquare & \multicolumn{1}{|c|}{ Kesimpulan } \\
\hline 62 & 0,000 & 0,01 & 0,479 & 0,230 & $\begin{array}{l}\text { Sig (2-tailed) 0,000 }<0,01 \\
\text { level of significant ( }), \\
\text { berarti hipotesis diterima }\end{array}$ \\
\hline
\end{tabular}

Berdasarkan uraian tabel di atas, maka diperoleh koefisien korelasi antara variabel lingkungan kerja fisik dengan kesehatan dan keselamatan kerjasebesar $r=0,479$ dengan taraf signifikansi $\mathrm{p}=0,000$, maka dapat disimpulkan bahwa ada hubungan antara lingkungan kerja fisik dengan kesehatan dan keselamatan kerjapada pasukan kuning di kota Padang dengan arah hubungan positif. Hal ini menunjukkan semakin baik lingkungan kerja fisik maka semakin tinggi kesehatan dan keselamatan kerjadan sebaliknya semakin buruk lingkungan kerja fisik maka semakin rendah kesehatan dan keselamatan kerja.

Berikut tabel deskriptif statisitik dari variabel dukungan sosial dan optimism terhadap masa depan berdasarkan mean empirik sebagai berikut.

\section{Tabel 8.}

Descriptive Statistic Skala Dukungan Sosial dan Optimisme Terhadap Masa Depan

\begin{tabular}{|l|c|c|c|c|c|}
\hline \multicolumn{1}{|c|}{ Variable } & N & Mean & Std. Deviation & Minimum & Maximum \\
\hline $\begin{array}{l}\text { Lingkungan } \\
\text { kerja fisik }\end{array}$ & 62 & 95,60 & 12,293 & 31 & 124 \\
\hline $\begin{array}{l}\text { Kesehatan dan } \\
\text { keselamatan } \\
\text { kerja }\end{array}$ & 62 & 117,58 & 16,019 & 39 & 156 \\
\hline
\end{tabular}

Berdasarkan nilai mean empirik, maka dapat dilakukan pengelompokkan yang mengacu pada kriteria pengkategorisasian dengan tujuan menempatkan individu kedalam kelompok-kelompok yang terpisah secara berjenjang menurut suatu kontinum berdasarkan atribut yang diukur (Azwar, 2014) ${ }^{[9]}$ dengan ketentuan sebagai berikut :

Tabel 9

Norma Kategorisasi

\begin{tabular}{|c|c|}
\hline Norma & Kategorisasi \\
\hline$X<(\mu-1,0 \sigma)$ & Rendah \\
\hline$(\mu-1,0 \sigma) \leq X<(\mu+1,0 \sigma)$ & Sedang \\
\hline$(\mu+1,0 \sigma) \leq X$ & Tinggi \\
\hline
\end{tabular}

Keterangan:

$\sigma=$ standardeviasi

$\mathrm{X}=$ raw score

$\mu=$ rata-rata 
Berdasarkan uraian tabel di atas, maka diperoleh kategorisasi subjek penelitian pada lingkungan kerja fisik dan kesehatan dan keselamatan kerjasebagai berikut:

Tabel 14. Pengelompokkan Kategorisasi Subjek

\begin{tabular}{|l|c|c|c|c|}
\hline \multicolumn{1}{|c|}{ Variabel } & Skor & Jumlah & Persentase (\%) & Kategori \\
\hline \multirow{2}{*}{$\begin{array}{l}\text { Lingkungan } \\
\text { kerja fisik }\end{array}$} & $31-83$ & 8 & $13 \%$ & Rendah \\
\cline { 2 - 5 } & $84-107$ & 43 & $69 \%$ & Sedang \\
\cline { 2 - 5 } $\begin{array}{l}\text { Kesehatan dan } \\
\text { keselamatan } \\
\text { kerja }\end{array}$ & $108-124$ & 11 & $18 \%$ & Tinggi \\
\cline { 2 - 5 } & $39-100$ & 7 & $11 \%$ & Rendah \\
\cline { 2 - 5 } & $101-132$ & 43 & $69 \%$ & Sedang \\
\hline
\end{tabular}

Berdasarkan tabel di atas, maka dapat diperoleh gambaran bahwa sebesar 13\% atau 8 orang pasukan kuning dikategorikan memiliki lingkungan kerja fisik yang rendah dan sebesar $69 \%$ atau 43 orang pasukan kuning dikategorikan lingkungan kerja fisik yang sedang dan sebesar $18 \%$ atau 11 orang pasukan kuning dikategorikan lingkungan kerja fisik yang tinggi sedangkan untuk variabel kesehatan dan keselamatan kerjadiperoleh gambaran bahwa sebesar $11 \%$ atau 7 orang pasukan kuning memiliki kesehatan dan keselamatan kerjayang rendah dan sebesar $69 \%$ atau 43 orang pasukan kuning memiliki kesehatan dan keselamatan kerjayang sedang dan sebesar $20 \%$ atau 12 orang pasukan kuning memiliki kesehatan dan keselamatan kerjayang tinggi.

\section{Sumbangan Efektif}

Besar sumbangan variabel Dukungan Sosialterhadap variabel Optimisme dapat ditentukan dengan menggunakan rumus koefisien determinan. Koefisien determinan adalah kuadrat dari koefisien korelasi yang dikali dengan 100\% (Nugroho dalam Latry, 2018) ${ }^{[12]}$. Derajat koefisien determinan dicari dengan menggunakan rumus sebagai berikut :

$$
\mathbf{K P}=\mathbf{r}^{2} .100 \%
$$

$$
\begin{aligned}
\text { Keterangan: } & \begin{array}{c}
\text { KP }=\text { Nilai Koefisien Determinan } \\
\mathrm{r} \quad=\text { Nilai Koefisien Korelasi }
\end{array} \\
\mathrm{KP} & =\mathrm{r}^{2} \times 100 \% \\
& =(0,479)^{2} \times 100 \% \\
& =23 \%
\end{aligned}
$$

Berdasarkan rumus tersebut maka dapat ditentukan bahwa besarnya sumbangan Dukungan Sosialterhadap Optimisme adalah sebesar 61\% dan 39\% lagi dipengaruhi oleh faktor lain.

\section{F. Kesimpulan dan Saran}

\section{Kesimpulan}

Berdasarkan hasil dan pembahasan yang telah dijelaskan, maka dapat ditarik kesimpulan bahwa :

a. Terdapat hubungan lingkungan kerja fisik dengan kesehatan dan keselamatan kerja pada pasukan kuning di kota Padang yang artinya semakin baik lingkungan kerja fisik maka semakin tinggi kesehatan dan keselamatan kerja pada pasukan kuning dan sebaliknya semakin buruk lingkungan kerja fisik maka semakin rendah kesehatan dan keselamatan kerja pada pasukan kuning di kota Padang, hal ini berarti hipotesis diterima.

b. Adapun sumbangan efektif dari variabel lingkungan kerja fisik terhadap variabel kesehatan dan keselamatan kerja yaitu sebesar $23 \%$. 
Rahma Dwi Putri, Harry Theozard Fikri

Jurnal PSYCHE 165 Vol 12 No 2 (2019) 183-192

\section{Referensi}

[1]Prasetyo, Anggun. R. 2015. Gambaran Career Happiness Plan Pada Dosen. Jurnal Fakultas Psikologi Universitas Diponegoro Vol.14 No.2 Oktober 2015, 174-182.

[2] Fakhrina, Syarifah. Y \& Asniar. 2017. Keselamatan dan Kesehatan Kerja Pada Petugas Kebersihan Di Kota Banda Aceh.Jurnal Program Studi Ilmu Keperawatan Universitas Syiah Kuala Banda Aceh.

[3] Maharani, Dwi. 2018. Manajemen Komunikasi pada Petugas Kebersihan Kota Palembang.Jurnal Komunikasi, Vol 11 (1), Juni 2018, 119-128.

[4] Saputra, Dody. 2012. Analisis Hubungan Keselamatan dan Kesehatan Kerja (K3) Terhadap Kepuasan Kerja Karyawan Di PT Dystar Colours Indonesia.Skripsi Program Sarjana Alih Jenis Manajemen Departemen Manajemen Fakultas Ekonomi Dan Manajemen Institut Pertanian Bogor.

[5] Irzal. 2016. Dasar-Dasar Kesehatan dan Keselamatan Kerja. Jakarta: Kencana

[6] Nitisemito, Alex. 2016. Manajemen Sumber Daya Manusia. Bandung: Pustaka Setia.

[7] Sedarmayanti. 2011. Tata Kerja dan Produktivitas Kerja. Bandung: CV. Mandar Maju.

[8] Sugiyono. 2014. Metode Penelitian Kuantitati, Kualitatif dan $R \& D$. Bandung: Penerbit Alfabeta.

[9] Azwar, Saifuddin. 2014. Penyusunan Skala Psikologi. Yogyakarta: Pustaka Pelajar.

[10] Arikunto, Suharsimi. 2010. Manajemen Penelitian Edisi Revisi. Jakarta: PT Rineka Cipta.

[11] Priyatno, Dwi. 2008. Mandiri Belajar SPSS: Bagi Mahasiswa dan Umum. Yogyakarta: MediaKom.

[12] Latry, Manik Jenlay. 2018. 'Hubungan antara dukungan social dengan optimisme terhadap masa depan pada remaja perempuan di Himpunan Wanita Disabilitas Indonesia(HWDI) di Kota Padang". Skripsi : "Fakultas Psikologi, Putra Indonesia University" YPTK "Padang 